\title{
ANALISIS KEMANDIRIAN USAHA MAHASISWA MELALUI INOVASI PRODUK, PEMANFAATAN TEKNOLOGI INFORMASI DAN MINAT BERWIRAUSAHA
}

\author{
Sukirman $^{1}$ \\ Prodi Manajemen, Universitas Muria Kudus, Gondangmanis \\ Bae PO BOX 53 Kudus, Jawa Tengah, Indonesia \\ Email: sukirman@umk.ac.id
}

Zaenal Afifi ${ }^{2}$

Prodi Akuntansi Fakultas Ekonomika dan Bisnis, Universitas Muria Kudus, Gondangmanis Bae PO BOX 53 Kudus, Jawa Tengah, Indonesia

\author{
Ahmad Zazuli ${ }^{3}$ \\ Prodi Teknologi Informasi, Universitas Muria Kudus, Gondangmanis \\ Bae PO BOX 53 Kudus, Jawa Tengah, Indonesia
}

\begin{abstract}
Abstrak: Calon pengusaha merupakan bagian penting dalam mengembangkan kemandirian usaha bagi mahasiswa. Inovasi produk usaha mahasiswa merupakan kekuatan utama dalam membentuk kemampuan mengembangkan minat berwirausaha. Tujuan penelitian ini adalah untuk menganalisis pengaruh inovasi produk dan pemanfaatan teknologi informasi terhadap kemandirian usaha mahasiswa melalui minat berwirausaha mahasiswa ketrampilan wajib kewirausahaan Universitas Muria Kudus. Jumlah sampel dalam penelitian ini 115 mahasiswa dengan menggunakan teorinya Ferdinant dan teknik probability sampling. Analisis data menggunakan teknik analisis jalur (Path Analysis). Hasil analisis menunjukkan bahwa inovasi produk dan pemanfaatan teknologi informasi berpengaruh terhadap kemandirian usaha, serta minat berwirausaha mampu menjadi mediasi inovasi produk dan pemanfaatan teknologi informasi terhadap kemandirian usaha mahasiswa, sehingga diperlukan bagi mahasiswa untuk mampu menciptakan inovasi peroduk dan meningkatakan pemanfaatan teknologi informasi agar bisa menjadi wira usaha yang mandiri.
\end{abstract}

Kata kunci: Inovasi Produk; Pemanfaatan Teknologi Informasi; Minat Berwirausaha; Kemandirian Usaha.

Absract: Prospective entrepreneurs are an important part in developing business independence for students. Student effort product innovation is a major force in shaping the ability to develop entrepreneurial interests. The purpose of this study was to analyze the effect of product innovation and the use of information technology on the independence of student business through student interest in entrepreneurial compulsory entrepreneurial skills at Muria Kudus University. The number of samples in this study were 115 students using Ferdinant's theory and probability sampling techniques. Data analysis using path analysis techniques (Path Analysis). The results of the analysis show that product innovation and the use of information technology affect business independence, and the interest in entrepreneurship is able to mediate product innovation and the use of information technology on the independence of student business, so it is needed for students to be able to create product innovation and increase the use of information technology so that they can become independent entrepreneurs.

Keywords: Product Innovation; Use of Information Technology; Entrepreneurial Interest; Business Independence.

Article History: Received 2020-03-07; Revised 2020-04-08; Accepted 2020-04-13

\section{PENDAHULUAN}

Meningkatkan produktivitas usaha dalam Pembangunan Jangka Panjang Nasional (PJPN 2005-2025) diperlukan adanya pemberdayaan usaha yang ditujukan pada pengembangan usaha bebasis iptek dan berdaya saing global. Strategi pemberdayaan usaha kecil diarahkan pada

Sukirman ${ }^{1}$, Zaenal Afifi ${ }^{2}$, Ahmad Zazuli ${ }^{3}$ - Analisis Kemandirian Usaha Mahasiswa Melalui Inovasi Produk, Pemanfaatan ... [Vol 11, No 1 (2020): April 2020] JBTI 
pembangunan kompetensi inovasi dan teknologi sehingga lebih berperan dalam pertumbuhan ekonomi. Perkembangan usaha mahasiswa hanya mampu menciptakan 1,5\% dari 826 mahasiswa peserta program pengembangan kewirausahaan, sehingga diperlukan adanya peningkatan kemandirian usaha bagi mahasiswa untuk mendorong pertumbuhan ekonomi melalui kewirausahaan mahasiswa guna mengembangkan minat berwirausaha menuju persaingan global. Frederick et al. (2015) menyatakan bahwa terbentuknya kemandirian usaha dipengaruhi oleh inovasi produk secara signifikan. Kemandirian usaha mahasiswa akan semakin kuat apabila minat berwirausaha semakin kuat (Rahayu et al., 2011).

Penelitian ini bertujuan untuk mengembangkan kemandirian usaha mahasiswa di Universitas Muria Kudus dengan mengangkat potensi unggulan khas daerah dan industri kreatif menuju pasar global. Unit usaha mahasiswa yang ada sebanyak 56 unit pada tahun 2015, dengan 125 tenaga kerja. Pada tahun 2016 terjadi peningkatan menjadi 60 unit usaha dengan 150 tenaga kerja. Perubahan terjadi pada tahun 2017 dengan jumlah unit usaha menjadi 63 dan tenaga kerja 156 karyawan. Atas dasar data hasil penjualan produk di kampus, terdapat sekitar $80 \%$ produk usaha mahasiswa yang mampu djual terutama produk konveksi, sovenir, rajut, jilbab, dan juga makanan seperti ayam geprek, kopi pojok, griya dahar dan sebagainya.

Keberhasilan mahasiswa dalam mengikuti seleksi Program Kewirausahaan Mahasiswa (PKM) tahun 2018 menghasilkan 25 proposal lolos seleksi, hal ini merupakan prestasi terbaik dibanding dengan tahun-tahun sebelumnya. Daya tarik mahasiswa dalam mengikuti PKM cukup tinggi yaitu mencapai 125 proposal, serta didukung dengan keinginan mahasiswa menjalankan usaha tahun ini mencapai 213 orang. Berdasarkan jumlah mahasiswa UMK kurang lebih 12.500 orang baru sekitar 213 orang yang berminat menjadi wira usaha. Kondisi ini memungkinkan untuk melakukan pengembangan kewirausahaan mahasiswa menjadi semakin kuat, selain itu juga didorong adanya keterampilam wajib kewirausahaan bagi semua mahasiswa S-1 di Universitas Muria Kudus. Atas dasar tersebut diperlukan keberanian membangun inovasi produk dalam berbagai aktivitas untuk menambah kuatnya minat berwirausaha (Malebana, 2014). Oleh sebab itu diperlukan adanya peningkatan kemandirian usaha mahasiswa melalui inovasi produk, pemanfaatan teknologi informasi dan minat berwirausaha.

\section{KAJIAN TEORI}

Inovasi merupakan usaha untuk melakukan perubahan yang disengaja dalam pekerjaan suatu organisasi mengenai ide, proses, produk atau prosedur yang baru dalam pekerjaan. Organisasi merancang untuk menciptakan sesuatu yang menguntungkan bagi perusahaan pada organisasi tersebut (Djodjobo \& Tawas, 2014). Inovasi diwujudkan dalam bentuk proses no-linear yang terdiri dari dua komponen utama meliputi implementasi kreativitas dan implementasi inovasi. Dalam dunia usaha inovasi terbagi menjadi dua tipe yang menciptakan keuntungan bagi dunia bisnis dengan cara yang berbeda yaitu inovasi produk dan inovasi proses (Djodjobo \& Tawas, 2014).

Inovasi produk merupakan pengembangan jenis barang maupun jasa yang baru dan berbeda dalam melengkapi kekurangan-kekurangan dari penemuan sebelumnya, serta lebih menekankan pada segi kualitas. Inovasi produk merupakan dampak dari perubahan teknologi yang cepat sehingga mampu menentukan kinerja organisasi. Inovasi yang tinggi diharapkan mampu meningkatkan kemampuan perusahaan menciptakan produk yang berkualitas dan mempunyai daya saing. Sanchez-Gutierrez et al. (2012) dalam mengukur inovasi produk menggunakan indikator sebagai berikut: (1) Menciptakan desain yang menarik. Menariknya suatu desain produk dapat menambah minat beli konsumen, kinerja produk meningkat, dan menciptakan keunggulan yang tinggi di pasar konsumen. (2) Standar kualitas. Standar kualitas diperlukan oleh suatu produk untuk memberikan nilai tambah, sehingga dihasilkan produk yang memiliki mutu tinggi. (3) 
Pengembangan kualitas. Suatu produk perlu dilakukan pengembangan kualitas supaya produk yang dihasilkan menjalankan fungsi-fungsinya dengan baik, serta dampaknya dapat menimbulkan persepsi sebagai produk yang berkualitas baik.

Djodjobo \& Tawas (2014) menjelaskan adanya beberapa indikator dari inovasi produk, yaitu: 1) Perluasan Produk (line extensions). Produk yang masih familiar bagi organisasi bisnis tetapi baru bagi pasar. 2) Peniruan Produk (me-too products). Produk yang dianggap baru oleh bisnis tetapi familiar dengan pasar. Entrepreneur dibedakan menjadi 10 kategori (Aprilianti, 2012) diantaranya adalah komitmen dan determinasi tidak terbatas, dorongan kuat untuk mencapai prestasi, orientasi kearah peluang-peluang, focus pengendalian internal, toleransi terhadap ambiguitas, keterampilan dalam menerima resiko, kurang dirasakan kebutuhan akan status dan kekuasaan, kemampuan untuk memecahkan masalah, kemampuan untuk mendapatkan "umpan balik" (feedback), dan kemampuan untuk menghadapi kegagalan.

Teknologi Informasi (TI) menurut (Alhaji, 2015) adalah seperangkat alat yang membantu untuk bekerja melalui informasi dan melakukan tugas-tugas yang berhubungan dengan pemrosesan informasi. TI menyediakan informasi yang dibutuhkan pelaku usaha untuk meningkatkan pengetahuan, memfasilitasi kelompok-kelompok usaha mahasiswa agar dapat mengembangkan kreativitas; serta menyediakan tempat bagi para tenant untuk mewujudkan ide kreatif menjadi produk inovatif yang mempunyai nilai jual. Fatoki (2014) mengatakan bahwa pemanfaatan TI memberikan nila positif bagi strategi manajemen yang terkait dengan aspek komunikasi, informasi, pengambilan keputusan, manajemen data dan knowledge management pada sebuah badan usaha.

Pelaku usaha dalam memanfaatkan TI dipengaruhi oleh dua faktor (Asfiatul, 2013) yaitu faktor internal terdiri dari keputusan pelaku usaha (top manajemen) diantaranya: terdapat modal, sumber daya manusia, aplikasi TI yang sesuai dengan kebutuhan usaha; dan faktor eksternal yang mempengaruhi lingkungan kompetitif (persaingan dengan usaha lain), pemerintah, pelangggan dan suplier, serta konsultan TI dan vendor. Ferreira et al. (2012) mengatakan bahwa pemahaman TI bagi pelaku usaha masih rendah dalam menunjang usaha. Hussain \& Norashidah (2015) menunjukkan bahwa pelaku usaha merasakan TI memiliki manfaat namun belum sepenuhnya digunakan karena sebagian besar pelaku usaha tidak berkaitan dengan komputer dalam menjalankan usaha.

Qomariah \& Dalimunthe (2011) mengungkapkan bahwa minat berwirausaha merupakan kesediaan kemandirian usaha bagi pelaku usaha. Penguatan pembiayaan serta kebijakan strategis dalam mengembangkan usaha kecil merupakan kekuatan eknomi yang mandiri untuk terbentuknya usaha kecil yang tangguh dan sehat. Mewujudkan tujuan tersebut diperlukan adanya kerja sama antara pemerintah dan masyarakat dalam mewujudkan kemandirian usaha untuk melaksanakan kegiatan sebelum beralih ke pemberdayaan masyarakat berikutnya. Pemberdayaan yang dilaksanakan dapat meningkatkan kemandirian ekonomi terutama pada produktivitas dan pendapatan masyarakat yang mendapatkan bantuan (Sanchez-Gutierrez et al., 2012). Minat berwirausaha merupakan keinginan, ketertarikan, dan kesediaan untuk bekeja keras dalam memenuhi kebutuhan hidup tanpa merasa takut dengan resiko yang terjadi, dan berkemauan keras untuk belajar dari kegagalan. Minat berwirausaha berdasarkan prespektif waktu dibedakan dalam empat tipe (Venesaar et al., 2006), yaitu: 1) minat berwirausaha dalam jangka waktu dekat, 2) minat berwirausaha pada dua tahun mendatang, 3) minat berwirausaha pada jangka panjang, dan 4) belum menentukan waktu untuk memulai.

Hubungan inovasi produk dengan minat berwirausaha menurut Siswandi (2013), dalam program pengembangan kewirausahaan tidak hanya memberi bekal teori, namun diperlukan berbagai pelatihan aplikatif dan inovatif yang mengarah aspek kewirausahaan dalam kehidupan. Suryana (2013) mengemukakan bahwa seseorang memiliki minat berwirausaha karena adanya suatu

Sukirman ${ }^{1}$, Zaenal Afifi ${ }^{2}$, Ahmad Zazuli ${ }^{3}$ - Analisis Kemandirian Usaha Mahasiswa Melalui Inovasi Produk, Pemanfaatan ...

[Vol 11, No 1 (2020): April 2020] JBTI 
motif, yaitu motif berprestasi. Motif berprestasi adalah suatu nilai sosial yang menekankan pada hasrat untuk mencapai hasil terbaik guna mencapai kemandirian pribadi.

\section{METODE PENELITIAN}

Jumlah sampel dalam penelitian ini ditentukan berdasarkan perkalian antara 5 sampai dengan 10 dikalikan dengan jumlah indikator (Hair et al., 2010). Terdapat 23 indikator yang menjadi pernyataan dalam kuesioner penelitian, sehingga jumlah sampel yang digunakan adalah $(5 \times 23)=$ 115 responden. Populasi penelitian ini adalah mahasiswa S-1 program ketrampilan wajib kewirausahaan tahun 2018/2019 Universitas Muria Kudus sebanyak 680 mahasiswa. Sampel diambil dengan metode probability sampling, menyodorkan kuesioner kepada responden yang sudah menjadi pelaku usaha.

Data diolah dengan menggunakan Structural Equation Modelling (SEM) dari software AMOS. Validitas diuji dengan tujuan untuk mengukur kuesioner, dikatakan valid jika dapat mengukur nilai variabel yang diteliti (Suliyanto, 2012). Uji reliabilitas digunakan untuk mengukur sejauh mana hasil suatu pengukuran dapat dipercaya, jika pengukuran dilakukan secara berulang hasilnya tetap sama, maka pengukuran dianggap mempunyai reliabilitas tinggi (Suliyanto, 2012).

Pengujian hipotesis dan analisis kuantitatif dilakukan dengan penyusunan model melalui: pengembangan model berbasis teori, menyusun diagram jalur (Path Diagram) dan diagram struktural, memilih jenis input matrik dan estimasi model yang diusulkan, menilai identifikasi model struktural, menilai kriteria goodnes-of-fit, interpretasi dan modifikasi model (Ghozali \& Fuad, 2014).

\section{HASIL DAN PEMBAHASAN Uji Validitas}

Uji validitas menggunakan alat analisis Amos versi 22 menunjukkan bahwa variabel Inovasi Produk, Pemanfaatan TI, Minat berwirausaha, dan Kemandirian Usaha memberikan nilai korelasi lebih besar dari 0,50 sehingga dapat dikatakan valid.

Tabel 1. Uji Validitas

\begin{tabular}{|c|c|c|c|}
\hline \multirow{2}{*}{ Variabel } & \multirow{2}{*}{ Item } & \multicolumn{2}{|c|}{ Validitas } \\
\cline { 3 - 4 } & & Korelasi & Keterangan \\
\hline \multirow{3}{*}{ Inovasi Produk } & X1.1 & 0,654 & Valid \\
& X1.2 & 0,687 & Valid \\
& X1.3 & 0,796 & Valid \\
& X1.4 & 0,765 & Valid \\
& X1.5 & 0,824 & Valid \\
\hline \multirow{3}{*}{ Pemanfaatan TI } & X2.1 & 0,548 & Valid \\
& X2.2 & 0,687 & Valid \\
& X2.3 & 0,605 & Valid \\
& X2.4 & 0,784 & Valid \\
& X2.5 & 0,626 & Valid \\
& X2.6 & 0,813 & Valid \\
\hline \multirow{3}{*}{ Minat Berwirausaha } & Y1.1 & 0,663 & Valid \\
& Y1.2 & 0,672 & Valid \\
& Y1.3 & 0,633 & Valid \\
& Y1.4 & 0,682 & Valid \\
& Y1.5 & 0,828 & Valid \\
& Y1.6 & 0,674 & Valid \\
& Y1.7 & 0,706 & Valid \\
\hline
\end{tabular}

Sukirman ${ }^{1}$, Zaenal Afifi ${ }^{2}$, Ahmad Zazuli ${ }^{3}$ - Analisis Kemandirian Usaha Mahasiswa Melalui Inovasi Produk, Pemanfaatan ... [Vol 11, No 1 (2020): April 2020] JBTI 


\begin{tabular}{|c|c|c|c|}
\hline \multirow{2}{*}{ Variabel } & \multirow{2}{*}{ Item } & \multicolumn{2}{|c|}{ Validitas } \\
\cline { 3 - 4 } & & Korelasi & Keterangan \\
\hline \multirow{3}{*}{ Kemandirian Usaha } & Y2.1 & 0,682 & Valid \\
& Y2.2 & 0,826 & Valid \\
& Y2.3 & 0,821 & Valid \\
& Y2.4 & 0,516 & Valid \\
& Y2.5 & 0,645 & Valid \\
\hline
\end{tabular}

Sumber : Data awal diolah

\section{Uji Reliabilitas}

Mengukur reliabilitas dalam penelitian ini menggunakan nilai composite reliability (CR) atau disebut juga nilai cut off value. Rule of tumb dari CR adalah > 0,7 untuk dikatakan indikator reliabel dan dapat digunakan dalam penelitian. Pengujian reliabilitas pada masing-masing variabel disajikan dalam tabel berikut :

Tabel 2. Uji Reliabilitas

\begin{tabular}{|r|l|c|c|c|}
\hline No & \multicolumn{1}{|c|}{ Variabel } & CR & $\mathbf{0 , 7 0 0}$ & Keterangan \\
\hline 1 & Inovasi Produk & 0,768 & 0,700 & Reliabel \\
\hline 2 & Pemanfaatan TI & 0,746 & 0,700 & Reliabel \\
\hline 4 & Minat berwirausaha & 0,864 & 0,700 & Reliabel \\
\hline 5 & Kemandirian Usaha & 0,716 & 0,700 & Reliabel \\
\hline
\end{tabular}

Sumber : Data awal diolah

Hasil uji reliabilitas variabel Inovasi Produk, Pemanfaatan TI, Minat Berwirausaha, dan Kemandiran usaha memberikan nilai CR di atas nilai cut-off nya sebesar 0,70 sehingga dapat dikatakan reliabel. Uji hipotesis menggunakan analisis SEM dengan tingkat signifikansi 5 persen, maka menghasilkan nilai Critical Ratio (CR) sebesar 1,96. Hipotesis diterima apabila nilai $\mathrm{t} \geq 1,96$ dan nilai probabilitas kurang dari 0,05 atau tanda $* * *$ pada output AMOS. Hipotesis ditolak apabila nilai $\mathrm{t} \leq 1,96$ dan nilai probabilitas $>0,05$. Hasil uji hipotesis ditunjukkan pada tabel berikut.

Tabel 3. Hasil Pengujian Hipotesis Penelitian.

\begin{tabular}{|c|l|c|c|c|}
\hline & \multicolumn{1}{|c|}{ Hipotesis } & CR & P & Hasil \\
\hline $\mathrm{H}_{1}$ & $\begin{array}{l}\text { Inovasi produk berpengaruh tehadap } \\
\text { minat berwirausaha }\end{array}$ & 2,876 &, 005 & Diterima \\
\hline $\mathrm{H}_{2}$ & $\begin{array}{l}\text { Pemanfaatan TI berpengaruh terhadap } \\
\text { minat berwirausaha }\end{array}$ & 2,784 &, 002 & Diterima \\
\hline $\mathrm{H}_{3}$ & $\begin{array}{l}\text { Inovasi produk berpengaruh terhadap } \\
\text { kemandirian usaha }\end{array}$ & 2,406 &, 001 & Ditolak \\
\hline $\mathrm{H}_{4}$ & $\begin{array}{l}\text { Pemanfaatan TI berpengaruh terhadap } \\
\text { kemandirian usaha }\end{array}$ & 1,863 &, 002 & Diterima \\
\hline $\mathrm{H}_{5}$ & $\begin{array}{l}\text { Minat berwirausaha berpengaruh } \\
\text { terhadap kemandirian usaha }\end{array}$ & 2,482 & &, \\
\hline
\end{tabular}

Sumber: Data awal diolah

Atas dasar Tabel 3 menunjukkan bahwa inovasi produk $(\mathrm{CR}=2,876 ; \mathrm{P}=0,005)$ dan Pemanfaatan TI $(\mathrm{CR}=2,784 ; \mathrm{P}=0,002)$ berpengaruh positif dan signifikan terhadap minat berwirausaha, dan juga inovasi produk $(\mathrm{CR}=2,406 ; \mathrm{P}=0,001)$ berpengaruh positif dan signifikan

Sukirman ${ }^{1}$, Zaenal Afifi ${ }^{2}$, Ahmad Zazuli ${ }^{3}$ - Analisis Kemandirian Usaha Mahasiswa Melalui Inovasi Produk, Pemanfaatan ... [Vol 11, No 1 (2020): April 2020] JBTI 
terhadap kemandirian usaha, dan pemanfaatan TI $(\mathrm{CR}=1,863 ; \mathrm{P}=0,615)$ tidak berpengaruh dan tidak signifikan terhadap kemandirian usaha. Sedangkan minat berwirausaha $(C R=2,482 ; P=0,002)$ berpengaruh positif dan signifikan terhadap kemandirian usaha.

Pengaruh langsung antar variabel menunjukkan bahwa, variabel yang mempunyai pengaruh paling kuat terhadap minat berwirausaha adalah inovasi produk dengan kontribusi sebesar 56,8 persen. Variabel minat berwirausaha berpengaruh besar tehadap variabel kemandirian usaha dengan kontribusi sebesar 68,3 persen.

Tabel 4. Direct Effects (Group number 1 - Default model)

\begin{tabular}{|c|c|c|c|}
\hline & $\mathrm{X}_{2}$ & $\mathrm{X}_{1}$ & $\mathrm{Y}_{1}$ \\
\hline $\mathrm{Y}_{1}$ &, 482 &, 568 &, 000 \\
\hline $\mathrm{Y}_{2}$ &, 012 &, 056 &, 683 \\
\hline
\end{tabular}

Sumber: Data awal diolah

Pengaruh tidak langsung penelitian ini ditunjukkan dalam tabel 5 bahwa seluruh variabel eksogen memiliki pengaruh tidak langsung terhadap variabel kemandirian usaha. Pengaruh tidak langsung yang paling kuat terhadap kemandirian usaha adalah pemanfaatan TI dengan kontribusi sebesar 38,6 persen.

Tabel 5. Indirect Effects (Group number 1 - Default model)

\begin{tabular}{|c|c|c|c|}
\hline & $\mathrm{X}_{2}$ & $\mathrm{X}_{1}$ & $\mathrm{Y}_{1}$ \\
\hline$Y_{1}$ &, 000 &, 000 &, 000 \\
\hline $\mathrm{Y}_{2}$ &, 386 &, 236 &, 000 \\
\hline
\end{tabular}

Sumber: Data awal diolah

Hasil pengujian model penelitian ini diperoleh pengaruh langsung dan pengaruh tidak langsung antar variabel, oleh karena itu diperlukan adanya pengukuran pengaruh total. Hasil pengukuran pengaruh total antar variabel ditunjukkan pada tabel 6.

Tabel 6. Total Effects (Group number 1 - Default model)

\begin{tabular}{|c|c|c|c|}
\hline & $\mathbf{X}_{\mathbf{2}}$ & $\mathbf{X}_{\mathbf{1}}$ & $\mathbf{Y}_{\mathbf{1}}$ \\
\hline $\mathrm{Y}_{1}$ &, 485 &, 164 &, 000 \\
\hline $\mathrm{Y}_{2}$ &, 362 &, 258 &, 664 \\
\hline
\end{tabular}

Sumber: Data awal diolah

Berdasarkan hasil analisis bisa ditarik kesimpulan bahwa untuk membentuk kemandirian usaha bagi mahasiswa program ketrampilan wajib kewirausahaan Universitas Muria Kudus yang perlu dikembangkan adalah memberdayakan minat berwirausaha pada mahasiswa dengan cara meningkatkan variabel yang paling dominan atau memiliki loading factor terbesar yaitu memperhatikan kembali mengembangkan inovasi produk, dimulai dari membangun pentingnya inovasi, kemudahan inovasi, efisiensi waktu, kemauan, dan bertanggung jawab dalam membangun inovasi produk untuk meningkatkan minat berwirausaha. Diperlukan adanya keberanian untuk membangun inovasi produk dalam berbagai aktivitas sehingga menambah kuatnya minat berwirausaha (Malebana, 2014). Diperlukan keberanian dalam menciptakan inisiatif dengan ditunjukkan adanya keaktifan, keuletan dan penuh inovatif dalam mengembangkan usaha, didukung dengan adanya motif persaingan melalui orientasi pada hasil dan wawasan ke depan (Suryana, 2013). Berdasarkan data tersebut maka minat berwirausaha mahasiswa program ketrampilan wajib

Sukirman ${ }^{1}$, Zaenal Afifi ${ }^{2}$, Ahmad Zazuli ${ }^{3}$ - Analisis Kemandirian Usaha Mahasiswa Melalui Inovasi Produk, Pemanfaatan ... [Vol 11, No 1 (2020): April 2020] JBTI 
kewirausahaan Universitas Muria Kudus dapat ditingkatkan dengan cara mengembangkan peningkatan inovasi produk dalam setiap melakukan aktivitas usaha.

Penelitian ini membuktikan bahwa inovasi produk mempunyai pengaruh yang positif dan signifikan terhadap minat berwirausaha (hipotesis pertama terdukung). Hal ini menunjukkan bahwa inovasi produk yang dilakukan mahasiswa program ketrampilan wajib kewirausahaan Universitas Muria Kudus mampu meningkatkan terbentuknya minat berwirausaha, mendorong serta menumbuhkan semangat bagi mahasiswa dalam melakukan kegiatan usaha. Penelitian ini mendukung hasil penelitian Husaini (2004) dan Suharti \& Sirine (2011) bahwa inovasi produk berpengaruh positif dan signifikan terhadap minat berewirausaha. Dengan demikian diartikan bahwa mahasiswa dituntut untuk mengedepankan inovasi produk dalam setiap kegiatan bisnis supaya dapat membentuk minat berwirausaha yang tinggi.

Pemanfaatan TI berpengaruh positif dan signifikan terhadap minat berwirausaha. Menunjukkan hipotesis kedua terbukti bahwa pemanfaatan TI yang dikembangkan oleh mahasiswa mampu mengembangkan minat berwirausaha demi kelangsungan bisnisnya. Penelitian ini sejalan dengan hasil penelitian Ghobakhloo et al. (2012) yang mengatakan bahwa pemanfaatan TI berpengaruh kuat terhadap minat berwirausaha. Atas dasar hasil tersebut membuktikan bahwa mahasiswa memiliki dasar pemanfaatan TI yang mampu meningkatkan minat berwirausaha. Pemanfaatan TI yang terdapat pada mahasiswa mampu mewujudkan terbentuknya minat berwirausaha dengan pengembangan serta pengambilan keputusan dalam menjalankan usaha. Keberanian untuk menggunakan TI serta pengambilan keputusan pada saat yang tepat merupakan tuntutan yang harus dilakukan mahasiswa karena merupakan aktifitas yang dipilih agar perusahaan tidak mengalami kegagalan (Lestari \& Wijaya, 2012).

Penelitian ini juga menunjukkan hasil bahwa minat berwirausaha mempunyai pengaruh terhadap kemandirian usaha. Sejalan dengan hasil penelitian Basuki (2007) yang mengatakan bahwa minat berwirausaha mempunyai pengaruh yang positif dan signifikan terhadap kemandirian usaha. Jika minat berwirausaha semakin kuat maka kemandirian usaha mahasiswa juga akan semakin kuat dalam menjalankan kegiatan usaha (Rahayu et al., 2011).

Penelitian ini juga menunjukkan bahwa inovasi produk mempunyai pengaruh terhadap kemandirian usaha. Semakin tinggi inovasi produk maka akan semakin kuat membentuk kemandirian usaha (Suharti \& Sirine (2011). Inovasi produk merupakan gabungan dari berbagai macam proses yang saling mempengaruhi antara yang satu dengan yang lain, dengan adanya inovasi produk, diharapkan dapat meningkatkan kemandirian usaha (Kotler dan Keller, 2016). Pelaku usaha harus dapat memodifikasi produk untuk menambah nilai dari produk yang dihasilkan dan mampu memenuhi kebutuhan konsumen. Semakin tinggi inovasi produk yang dihasilkan maka akan semakin tinggi pula kemandirian usaha perusahaan.

Hasil penelitian ini menunjukkan bahwa pemanfaatan TI tidak berpengaruh terhadap kemandirian usaha, sehingga walaupun mahasiswa mampu memanfaatkan TI dengan baik, tidak selalu akan membentuk kemandirian usaha. Hasil ini sesuai dengan penelitian Haryono \& Khoiriyah (2012) dan Setiawan (2012) yang menyatakan bahwa pemanfaatan TI tidak berpengaruh terhadap terbentuknya kemandirian usaha.

Inovasi produk mampu meningkatkan kemandirian usaha yang signifikan secara tidak langsung dengan dimediasi oleh minat berwirausaha, hasil ini sejalan dengan penelitian yang dilakukan Villonensia (2009). Prioritas yang diperlukan bagi mahasiswa program ketrampilan wajib kewirausahaan dalam membentuk kemandirian usaha adalah dengan memberdayakan mahasiswa dalam upaya melakukan inovasi produk dengan cara menguatkan minat berwirausaha yang baik. Hasil ini sesuai dengan penelitian Frederick et al. (2015) dan Choueke \& Armstrong (1998) yang menyatakan bahwa inovasi produk berpengaruh postif dan signifikan terhadap terbentuknya kemandirian usaha. 
Pemanfaatan TI mampu meningkatkan terbentuknya kemandirian usaha secara tidak langsung apabila dimediasi oleh minat berwirausaha, sehingga perlakuan utama terhadap terbentuknya kemandirian usaha adalah perlu adanya peningkatan minat berwirausaha dengan menciptakan kemampuan memanfaatkan TI bagi mahasiswa demi terwujudnya minat berwirausaha yang kuat. Peningkatan pemanfaatan TI tidak berpengaruh secara langsung terhadap peningkatan kemandirian usaha, hasil ini bertentangan dengan penelitian Thobias et al. (2013), Sukirman \& Indrayani (2014), dan Hendarwan (2018) yang menyatakan bahwa pemanfaatan TI mempunyai pengaruh terhadap terbentuknya kemandirian usaha. Thompson et al (1991) menyebutkan bahwa pemanfaatan teknologi informasi merupakan manfaat yang diharapkan oleh pengguna sistem informasi dalam melaksanakan tugasnya untuk memanfaatkan teknologi pada saat melakukan pekerjaan. Pengukuran berdasarkan intensitas pemanfaatan, frekuensi pemanfaatan dan jumlah aplikasi yang digunakan. Semakin banyak jumlah aplikasi yang diterapkan mengakibatkan pengguna kurang berminat dalam memanfaatkan TI untuk kepentingan bisnisnya, sehingga mengurangi kemandirian dalam melaksaksanakan pekerjaan (Bayu S dan Yayat, 2016). Pemanfaatan TI mampu meningkatkan minat bewirausaha mahasiswa, akibatnya semakin banyak mahasiswa yang berminat menjalankan usaha akan berpengaruh terhadap peningkatan kemadirian usaha mahasiswa.

\section{KESIMPULAN DAN SARAN}

Penguatan inovasi produk mampu menimbulkan dampak pada peningkatan kemandirian usaha, baik secara langsung maupun tdak langsung melalui peningkatan minat berwirausaha. Semakin kuat inovasi produk yang diciptakan maka akan semakin kuat pula minat berwirausaha yang terbentuk, dan dampaknya akan semakin kuat terbentuknya kemandirian usaha yang dilakukan oleh pelaku usaha mahasiswa. Terbentuknya kemandirian usaha karena didukung adanya peningkatan inovasi produk yang secara tidak langsung juga dipengaruhi adanya peningkatan minat berwirausaha bagi mahasiswa ketrampilan wajib kewirausahaan Universitas Muria Kudus.

Penguatan pemanfaatan TI mampu meningkatkan pembentukan kemandirian usaha melalui minat berwirausaha, artinya apabila pemanfaatan teknologi informasi semakin baik maka dapat meningkatkan tumbuhnya minat berwirausaha yang akhirnya mampu menciptakan peningkatan kemandirian usaha bagi pelaku usaha mahasiswa. Peningkatan pemanfaatan TI yang dibentuk oleh pelaku usaha mahasiswa tidak mampu secara langsung meningkatkan terbentuknya peningkatan kemandirian usaha, dikarenakan pemahaman tentang teknologi infomasi yang didasari dengan ketidaktahuan terhadap sistem yang baru dapat menyebabkan kegagalan dalam menggunakan teknologi informasi dalam dunia usaha.

Perlu adanya pemikiran dan tindakan yang komprehensif dalam menangani masalah-masalah pemberdayaan mahasiswa dengan lebih meningkatkan keterlibatan perguruan tinggi, stakeholders, dan pemerintah. Mahasiswa yang masih mengalami inovasi produk rendah, diperlukan adanya pemgembangan keyakinan, optimisme, serta mampu membentuk komitmen dengan melalui disiplin, didukung dengan kemampuan membentuk perubahan yang dilandasi terwujudnya inovasi produk dalam mengambil keputusan dengan resiko yang penuh tanggung jawab. Pemberdayaan mahasiswa dengan mengelola perubahan melalui inovasi produk diharapkan dapat menciptakan mahasiswa menjadi pelaku usaha yang tangguh dalam menghadapi persaingan. Diperlukan adanya perubahan pengelolaan pemanfaatan TI bagi mahasiswa, supaya lebih dikembangkan model operasional usaha dengan harapan akan lebih efisien, efektif serta mengurangi kebiasaan-kebiasaan yang tidak mendukung terbentuknya kemandirian usaha.

Keterlibatan perguruan tinggi sangat dibutuhkan dalam memberdayakan keahlian mahasiswa melalui pelatihan untuk memanfaatan TI yang memerlukan keterampilan khusus seperti laporan keuangan, pemasaran online, serta hubungan dengan relasi sehingga akan mempermudah akses serta mempunyai daya saing. Minat berwirausaha mahasiswa memerlukan dukungan keberanian agar dapat dengan mudah untuk menjalankan usaha, oleh karena itu dibutuhkan peran serta 
pemerintah daerah, perguruan tinggi dan stakeholders untuk mewujudkan adanya kerja sama dalam pengelolaan mahasiswa untuk dapat menjadi pelaku usaha. Oleh karena itu dapat meningkatkan terciptanya pelaku usaha dari mahasiswa serta berdampak pada pertumbuhan usaha yang sinergis dalam menjamin kelangsungan hidup perusahaan.

\section{DAFTAR PUSTAKA}

Alhaji, A. (2015). Entrepreneurship education and its impact on self-employment intention and entrepreneurial self-efficacy. Humanities and Social Sciences, 3(1), 57-63.

Aprilianti, E. (2012). Pengaruh kepribadian wirausaha, pengetahuan kewirausahaan, dan lingkungan terhadap minat berwirausaha siswa SMK. Jurnal Pendidikan Vokasi, 2(3), 311-324.

Asfiatul, F. (2013). Pengaruh Pendidikan \& Pelatihan, Prestasi Belajar Kewirausahaan terhadap Sikap Kewirausahaan Peserta didik SMK N 1 Cerme. Jurnal Kebijakan Dan Pengembangan Pendidikan, 1(2), 173-184.

Basuki, R. (2007). Analisis Hubungan antara Motivasi, Pengetahuan Kewirausahaan, dan Kemandirian Usaha terhadap Kinerja Pengusaha pada Kawasan Industri Kecil di daerah Pulogadung. Jurnal Usahawan, 2(10), 1-8.

Baso S., Yayat DH. (2016). Penggunaan Teknologi Informasi di Kalangan Pelaku Usaha Mikro Kecil Menengah di Daerah Perbatasan (Studi di Kabupaten Belu Provinsi Nusa Tenggara Timur) Jurnal Pekommas, Vol. 1 No. 2, Oktober 2016: 141 - 152.

Choueke, R., \& Armstrong, R. (1998). The learning organisation in small and medium-sized enterprises: A destination or a journey? International Journal of Entrepreneurial Behaviour \& Research, 4(2), 129-140.

Djodjobo, C. V., \& Tawas, H. N. (2014). Pengaruh orientasi kewirausahaan, inovasi produk, dan keunggulan bersaing terhadap kinerja pemasaran usaha nasi kuning di Kota Manado. Jurnal EMBA, 2(3), 1214-1224.

Fatoki, O. (2014). The Entrepreneurial Intention of Undergraduate Students in South Africa: The Influences of Entrepreneurship Education and Previous Work Experience. Mediterranean Journal of Social Sciences, 5(7), 294-299.

Ferreira, J. J., Raposo, M. L., Rodrigues, R. G., Dinis, A., \& do Paço, A. (2012). A model of entrepreneurial intention: An application of the psychological and behavioral approaches. Journal of Small Business and Enterprise Development, 19(3), 424-440.

Frederick, H., O’Connor, A., \& Kuratko, D. F. (2015). Entrepreneurship : Theory, Process and Practice (4th ed.). South Melbourne: Cengage Learning.

Ghobakhloo, M., Hong, T. S., Sabouri, M. S., \& Zulkifli, N. (2012). Strategies for successful information technology adoption in small and medium-sized enterprises. Information, 3(1), 36-67.

Ghozali, I., \& Fuad. (2014). Structural Equation Modeling: Teori, Konsep Dan Aplikasi Dengan Program Lisrel 9.10 (4th ed.). Semarang: Badan Penerbit UNDIP.

Hair, J., Black, W., Babin, B., \& Anderson, R. (2010). Multivariate Data Analysis (7th ed.). Pearson.

Haryono, T., \& Khoiriyah, S. (2012). Pengaruh Perilaku Kewirausahaan terhadap Kinerja Usaha Kecil dan Menengah (Studi Kasus pada UMKM di Surakarta). Jurnal Online Universitas Negeri Sebelas Maret.

Hendarwan, D. (2018). Menumbuhkan Jiwa, Perilaku dan Nilai Kewirausahaan dalam Meningkatkan Kemandirian Bisnis. MBIA, 17(2), 59-68.

Husaini. (2004). Pengembangan Jiwa Kewirausahaan Melalui Peningkatan Pendidikan Kejuruan di Kabupaten Indragiri Hilir. Tesis, Institut Pertanian Bogor.

Hussain, A., \& Norashidah. (2015). Impact of Entrepreneurial Education on Entrepreneurial Intentions of Pakistani Students. Journal of Entrepreneurship and Business Innovation, 2(1),

Sukirman ${ }^{1}$, Zaenal Afifi ${ }^{2}$, Ahmad Zazuli ${ }^{3}$ - Analisis Kemandirian Usaha Mahasiswa Melalui Inovasi Produk, Pemanfaatan ...

[Vol 11, No 1 (2020): April 2020] JBTI 
43-53.

Kotler, Philip and Kevin Lane Keller, (2016). Marketing Managemen, 15th Edition, Pearson Education,Inc.

Lestari, R. B., \& Wijaya, T. (2012). Pengaruh Pendidikan Kewirausahaan terhadap Minat Berwirausaha Mahasiswa di STIE MDP, STMIK MDP, dan STIE MUSI. Forum Bisnis Dan Kewirausahaan Jurnal Ilmiah STIE MDP, 1(2), 112-119.

Malebana, J. (2014). Entrepreneurial intentions of South African rural university students: A test of the theory of planned behaviour. Journal of Economics and Behavioral Studies, 6(2), 130-143.

Qomariah, I., \& Dalimunthe, D. M. J. (2011). Pengaruh pengetahuan kewirausahaan, motif berprestasi, dan kemandirian pribadi terhadap daya saing usaha (Pengusaha Kuliner Skala Kecil di Jalan Dr. Mansur Medan). Jurnal Ekonomi, 14(1), 20-25.

Rahayu, M., Novadjaja, L. H., \& Indrawati, N. K. (2011). Intensi Berwirausaha pada Mahasiswa Baru. Jurnal Aplikasi Manajemen, 9(2), 329-339.

Sanchez-Gutierrez, J., Gonzalez-Uribe, E. G., Gutierrez-Govea, A., \& Garcia-Jimenez, E. F. (2012). The effects of intellectual capital and innovation on competitiveness: An analysis of the restaurant industry in Guadalajara, Mexico. Journal of Competitiveness Studies, 20(3/4), 3346.

Setiawan, H. (2012). Pengaruh Orientasi Pasar, Orientasi Teknologi dan Inovasi Produk Terhadap Keunggulan Bersaing Usaha Songket Skala Kecil di Kota Palembang. Jurnal Orasi Bisnis, $8(2), 12-19$.

Siswandi, Y. (2013). Analisis Faktor Internal, Faktor Eksternal dan Pembelajaran Kewirausahaan yang Mempengaruhi Minat Mahasiswa dalam Berwirausaha. Jurnal Ilmiah Manajemen Dan Bisnis, 13(1), 1-17.

Suharti, L., \& Sirine, H. (2011). Faktor-Faktor yang Berpengaruh Terhadap Niat Kewirausahaan (Entrepreneurial Intention): Studi Terhadap Mahasiswa Universitas Kristen Satya Wacana, Salatiga. Jurnal Manajemen Dan Kewirausahaan, 13(2), 124-134.

Sukirman, \& Indrayani, M. (2014). Strategi Pemberdayaan Usaha Kecil Menuju Kemandirian Usaha dengan Menerapkan Manajemen Profesional. Jurnal Ilmu Manajemen, 4(1), 1-14.

Suliyanto. (2012). Metode Riset Bisnis. Yogyakarta: Andi Offset.

Suryana. (2013). Kewirausahaan: Kiat dan Proses Menuju Sukses (4th ed.). Jakarta: Salemba Empat.

Thobias, E., Tungka, A. K., \& Rogahang, J. J. (2013). Pengaruh Modal Sosial terhadap Perilaku Kewirausahaan (Suatu studi pada pelaku usaha mikro kecil menengah di Kecamatan Kabaruan Kabupaten Kepulauan Talaud). ACTA DIURNA, 2(2), 1-23.

Thompson Ronald, Christoper A and Howell Jane. (1991). Personal Computing : Toward a Conceptual Model of Utilization. MIS Quarterly. March 1991

Venesaar, U., Kolbre, E., \& Piliste, T. (2006). Students' Attitudes and Intentions toward Entrepreneurship at Tallinn University of Technology. TUTWPE, 154, 97-114.

Villonensia, P. (2009). Pengaruh Kemandirian Pribadi Terhadap Perilaku Kewirausahaan (Studi Kasus Pedagang Pakaian Pasar Pajak Sore Jalan Jamin Ginting). Skripsi, Universitas Sumatera Utara.

Sukirman ${ }^{1}$, Zaenal Afifi ${ }^{2}$, Ahmad Zazuli ${ }^{3}$ - Analisis Kemandirian Usaha Mahasiswa Melalui Inovasi Produk, Pemanfaatan ... [Vol 11, No 1 (2020): April 2020] JBTI 